\title{
1 How hot are the Cairngorms?
}

2 Jon Busby $^{1^{*}}$, Martin Gillespie ${ }^{2}$ and Sev Kender ${ }^{1}$

$4 \quad{ }^{1}$ British Geological Survey, Keyworth, Nottingham, NG12 5GG, UK

$5 \quad 2$ British Geological Survey, West Mains Road, Edinburgh, EH9 3LA, UK

6 * Corresponding author (email: jpbu@bgs.ac.uk)

\section{Synopsis}

9 Heat flow measured over the East Grampians batholith in the 1980s was found to be 10 unexpectedly low and at odds with high radiogenic heat production within the outcropping granites and a very large volume of granite predicted from an interpretation of gravity data. Past climate variations perturb temperature gradients in the shallow sub-surface leading to erroneous estimates of heat flow. A reconstruction of the surface temperature history during the last glacial cycle has enabled a rigorous palaeoclimate correction to be applied to the heat flow that shows an increase of $25 \%$ over previously reported values; revised to $86 \pm 7 \mathrm{mWm}^{-}$ 2. An interpretation of recent mapping reveals that the surface exposures of the East Grampians granites are the roof zones of a highly evolved magma system. Rock composition therefore is likely to become more mafic with depth and the heat production will decrease with depth. This petrological model can be reconciled with the gravity data if the shape of the batholith is tabular with deep seated feeder conduits. The increased heat flow value leads to revised predictions of sub-surface temperatures of $129{ }^{\circ} \mathrm{C}$ at $5 \mathrm{~km}$ depth and $176{ }^{\circ} \mathrm{C}$ at $7 \mathrm{~km}$ depth, increases of $40 \%$ and $49 \%$ respectively compared to previous estimates. These temperatures are at the lower end of those currently required for power generation with Engineered Geothermal Systems, but could potentially be exploited as a direct heat use resource in the Cairngorm region by targeting permeable fractures with deep boreholes.

\section{Introduction}

27 Engineered Geothermal Systems (EGS) are reservoirs that have been created to extract economical amounts of heat from low permeability and/or porosity geothermal resources (MIT 2006). In regions of the world with average continental heat flows, EGS is often associated with granites that have elevated concentrations of the naturally occurring radioelements of uranium (U), thorium (Th) and potassium (K). Where large volumes of such rocks occur, the radioactive decay of these elements produces heat anomalies at depth; these intrusions are therefore known as high-heat producing (HHP) granites. The geothermal 
energy they contain can in theory be exploited by pumping cold water down a borehole into a zone of hot rocks where it is heated as it travels through fractures of an engineered reservoir to a second borehole, from which it is extracted. The heat is then transferred to a binary fluid (that has a lower boiling point than water) via a heat exchanger which then turns a turbine to generate electricity. The highest reported heat flow in the UK of $\sim 130 \mathrm{~mW} \mathrm{~m}^{-2}$ was measured (Wheildon et al. 1981) in the Permian granite intrusions of Cornwall and Devon (surface expressions of the Cornubian batholith) and these intrusions have been extensively investigated as potential EGS reservoirs (e.g. Downing \& Gray 1986a, b; Batchelor 1987; Richards et al. 1994). The potential for EGS in Scotland was assessed during the Geothermal Energy programme (Rollin 1982, 1984; Lee 1984; Webb \& Brown 1984; Wheildon et al. 1984; Lee et al. 1984, 1987). There are no major late Carboniferous to Permian granite intrusions in Scotland, and therefore no direct analogues of the south-west England intrusions. The East Grampians batholith (EGB) underlies an east-west trending zone extending inland from Aberdeen. Many large Siluro-Devonian granite intrusions crop out within this zone and, from geochemical determinations of $\mathrm{U}$, Th and $\mathrm{K}$ a number were found to have the highest heat production (HP) values in the UK (Webb \& Brown, 1984) (see Table 1 and Figure 1). Subsequent heat flow measurements in shallow boreholes ( 300 m deep) at Cairngorm, Mount Battock, Ballater and Bennachie of 70, 59, 71 and $76 \mathrm{mWm}^{-2}$ respectively were much lower than anticipated from the heat production data (Wheildon et al. 1984) and were therefore disappointing.

The East Grampians batholith is associated with an extensive Bouguer gravity anomaly low that has a minimum magnitude of $-53 \mathrm{mGal}$ (see Figure 2). Modelling of this gravity anomaly (Rollin 1984, 2009) suggested that the granite intrusions may extend to between 9 and $13 \mathrm{~km}$ depth as one large intrusive mass with an approximate volume of granite of $25000 \mathrm{~km}^{3}$. In order to reconcile the disparity between high heat production and low heat flow, Wheildon et al. (1984) modelled the heat flow at each of the heat flow boreholes. It was concluded that heat production must decline rapidly with depth within the granite and that the background regional heat flow must be relatively low. The rapid decrease in heat production was ascribed to strong vertical fractionation of the radiothermal elements; in other words, the concentrations of $\mathrm{U}$, Th and K diminish rapidly with depth, so that the HHP character of the intrusions is just a near-surface feature. This interpretation was based, to a large extent, on a theoretical understanding of granite magma evolution, the geochemical data derived from samples from the relatively narrow vertical range spanned by the boreholes ( 300 m) and 
surface exposures (Webb \& Brown 1984; Webb et al. 1985). The heat flow modelling therefore predicted a sub-surface temperature at $5 \mathrm{~km}$ depth of $92^{\circ} \mathrm{C}$. When considered against predicted temperatures of $182^{\circ} \mathrm{C}$ at $5 \mathrm{~km}$ depth for parts of the Cornubian Batholith (Downing \& Gray 1986a) the East Grampians were judged as geothermally unprospective.

It is known that past climate change can perturb sub-surface temperature gradients from which heat flow is calculated (e.g. Benfield 1939; Birch 1948; Crain 1968; Jessop 1971; Beck 1977). In Britain, warming since the last glaciation would result in a positive correction to heat flow which Younger et al. (2012) and Westaway \& Younger (2013) suggested to be of the order of $\sim 20 \mathrm{~mW} \mathrm{~m}^{-2}$. Corrections to heat flow for palaeoclimate were not originally applied to the East Grampians heat flow boreholes (Downing \& Gray 1986a). The reason stated was that it was unnecessary for comparative regional studies, although this would then preclude using heat flow for predicting temperatures at depth. Westaway \& Younger (2013) have recently published a climate corrected heat flow value for the Ballater borehole of 89.5 $\mathrm{mWm}^{-2}$, a $26 \%$ increase over the original value. Hence, it is quite likely that a lack of consideration of palaeoclimate has resulted in an underestimate of heat flow, and by implication geothermal potential, of the East Grampians.

This paper presents a rigorous palaeoclimate correction to East Grampians heat flow and, with more recent petrological data on the intrusions, considers the implications for the geothermal resource.

\section{The East Grampians heat flow boreholes}

As part of the UK Geothermal Energy Programme (Downing \& Gray 1986a) heat flow boreholes were drilled into the Cairngorm, Mount Battock, Ballater and Bennachie intrusions. The Monadhliath intrusion, which is also of HHP character, was not included due to poor accessibility. In each case a single vertical borehole was sunk to around 300 metres and core was recovered in three short ( $<7$ metre) sections at approximately 100, 200 and 300 metres (amounting to $~ 5 \%$ of the total drilled depth). HP values for surface samples were affected by uranium mobility in the surface and near-surface environment, so a second set of 'preferred' HP values were calculated from unweathered rock recovered in core discs and chippings. The four intrusions consist of granite sensu stricto with subordinate proportions of coarser (pegmatitic) and finer (microgranitic and aplitic) granitic rock. Variations in grain-size and in the degree to which phenocrysts of feldspar are developed are characteristic features of all the 
internal divisions. Zones of hydrothermally altered rock, which probably formed shortly after emplacement, are common. The passage of hot water through these zones has produced a range of secondary minerals (notably hematite, epidote and chlorite), quartz veining and joints, which act to locally weaken the rock mechanically, lower its overall thermal conductivity and raise its permeability.

104 Downhole temperatures were measured with a thermistor probe suspended on a cable that was calibrated against a platinum resistance thermometer and was capable of measuring inhole temperatures to $\pm 0.01^{\circ} \mathrm{C}$. Due to the transient disturbance of downhole temperatures by the drilling, borehole temperatures were monitored for several months until no change was observed before an equilibrium temperature log was run. Thermal conductivities of recovered borehole samples were measured with the divided bar technique using discs cut from the cored sections and chippings for the rest of the boreholes. Samples were flooded with water under vacuum and subjected to axial stress up to $7 \mathrm{MPa}$ in the divided bar in order to simulate natural conditions (Wheildon et al. 1984).

\section{Calculation of heat flow}

114 There are a number of techniques for calculating heat flow. The heat flow $\mathrm{Q}_{\mathrm{d}}$ at depth $\mathrm{d}$ is 115 given by

$$
Q_{d}=\lambda_{d} \times\left(\frac{\delta T}{\delta z}\right)_{d}
$$

116 where $(\delta \mathrm{T} / \delta \mathrm{z})_{\mathrm{d}}$ is the temperature gradient over the interval of thermal conductivity $\lambda_{\mathrm{d}}$. A 117 technique that combines all the observations from the borehole is the step-integrated heat 118 flow equation of Bullard (1939). The relationship between the thermal resistance $\mathrm{R}$ and the 119 temperature $\mathrm{T}$ is linear for conductive, steady-state vertical heat flow with no internal heat 120 production, i.e.

$$
T_{z}=T_{o}+Q \sum_{i}\left(\frac{\Delta z_{i}}{\lambda_{i}}\right)
$$

121 Where $\mathrm{R}=\sum_{i}\left(\frac{\Delta z_{i}}{\lambda_{i}}\right), \lambda_{\mathrm{i}}$ is the thermal conductivity of the ith layer of thickness $\Delta \mathrm{z}_{\mathrm{i}}, \mathrm{T}_{\mathrm{o}}$ is the mean ground surface temperature and Q is the heat flow. Wheildon et al. (1984) used 123 equation (2) when calculating the original heat flow values for the East Grampians intrusions. 124 Errors can be introduced when using the step integrated heat flow equation if any sections of 125 the borehole are subjected to convective heat transport; an indication of this is shown by 
irregular temperature gradients. Hence, for this study, heat flow in each borehole has been recalculated using equation (1) over several 20-30 m thick intervals, at or below $100 \mathrm{~m}$, that are associated with uniform temperature gradients. The quoted, uncorrected, heat flow for each borehole is the average of the interval measurements and these new values are shown in Table 1. Two heat flow values are shown for Bennachie. This is because there is an increase in measured thermal conductivity in the depth interval 210-280 m that is not associated with a decrease in the temperature gradient. This implies that there may be an error in the thermal conductivities from the lower section of the borehole, although Wheildon et al. (1984) did not discuss these higher thermal conductivities. Hence for Bennachie one heat flow measurement is based on an analysis of the whole borehole (90-280 m), whilst a second is calculated from measurements in the upper section (90-200 m) of the borehole.

\section{Correction for palaeoclimate}

It is necessary to apply a correction for the effects of past climate variations as these will perturb temperature gradients in the ground from which heat flow is calculated. For simplified modelling purposes palaeoclimate can be considered as a series of one-off surface temperature changes that will affect sub-surface temperatures depending on the magnitude of the change in surface temperature and the time that has elapsed since the change. A surface temperature history for the Quaternary consists of a series of cyclical (e.g. glacial-interglacial cycles) to pseudo-cyclical (e.g. Dansgaard-Oeschger events) changes in temperature between warmer and colder conditions. Each cycle can last from a few hundred to several thousand years. The change in surface temperature will propagate into the ground, but the amplitude of the change will decrease exponentially with depth and there is a time lag between the temperature perturbation at the surface and at depth. The rate of the exponential decrease and the time lag are both dependent on the thermal diffusivity of the geological strata. Representing the surface temperature history as a series of step changes in temperature, Carslaw \& Jaeger (1959) have shown that

$$
T_{\theta}=T_{0} \times \operatorname{erfc}[z / 2 \sqrt{\kappa t}]
$$
where $T_{\theta}$ is the departure from original equilibrium temperature at depth $\mathrm{z}$ and time $\mathrm{t}$ after an instantaneous change in surface temperature of $T_{0} \kappa$ is the average thermal diffusivity of the geological strata down to depth $\mathrm{z}$ and $\operatorname{erfc}(\mathrm{x})$ is the complementary error function. Noting that the change in surface temperature is the difference in temperature between successive steps, the effect of more than one temperature step is found by addition of all the steps, i.e. 
159 Where $\mathrm{T}_{\theta \mathrm{i}}$ is the temperature deviation due to the ith event (Beck 1977; Beardsmore \& Cull 160 2001). An account of the theory for palaeoclimate correction from first principles is given by 161 Westaway \& Younger (2013). This temperature deviation is subtracted from the measured 162 temperature to generate the undisturbed temperature distribution in the ground from which a 163 palaeoclimate corrected heat flow is calculated.

165 For the East Grampians region the magnitude of the climate correction to heat flow depends on the surface thermal history during the last glacial-interglacial cycle, considered to extend back to $126 \mathrm{kyr}$ BP (thousand years before present) and in particular the extent of warming since the coldest period (often referred to as the Last Glacial Maximum or LGM, 20 kyr $\mathrm{BP})$. There are several proxies for past land surface temperature, which include fossil pollen and beetle assemblages, and although each has its uncertainties, multiple proxy data used together can provide reasonably robust reconstructions. Some generalised surface

172 temperature histories have been published; Beck (1977) generated a thermal history for the northern hemisphere at three different latitudes and Westaway \& Younger (2013) attempted a reconstruction for the southern and northern UK over the last 150 kyr based on a combination of climate proxy records including sea surface temperature (SST) and ice core temperature data. The approach here has been to produce a surface temperature history specific to the Cairngorms region, rather than to use a regionalised temperature history (c.f. Westaway \& Younger 2013). We attempt to capture the localised advance and retreat of glacier ice and the temperature beneath the ice, which can vary rapidly over relatively short distances (Hall \&

180 Glasser 2003). This has been achieved by reconstructing the shape of the last glacialinterglacial cycle temperature history for the UK from nearby mean annual air temperature (MAAT) reconstructions, scaling the curve for the Cairngorms latitude and modifying the surface temperature for periods of ice cover. This is detailed below.

Time interval 0-12 kyr BP

185 For this interval pollen records are available across Europe, including the UK, which have been quantitatively analysed by Davis et al. (2003). Based on this large dataset (500 sites), these authors produced MAAT records for six different regions of Europe. The 'central west' MAAT curve has been followed for the last $12 \mathrm{kyr}$ (Figure 3), as this is the region in closest proximity to the UK. In this reconstruction the temperature anomaly (relative to present day temperature) for the Younger Dryas (11-12 kyr BP) is $-4^{\circ} \mathrm{C}$. 
192 This important interval encompasses the LGM and the complicated, subsequent, deglaciation

193 (transition from the LGM to the onset of the current, Holocene, interglacial). The most 194 comprehensive analysis of the MAAT history for this interval is provided by the study of 195 Shakun et al. (2012) which summarises 80 records of both sea surface and land surface 196 proxies to reconstruct global latitudinal temperature curves. Their temperature curve 197 corresponding to $30-60^{\circ} \mathrm{N}$ is used here (Figure 3).

198 Time interval 22-40 kyr BP

199 For this interval there are no available regional time-series compilations of MAAT, and 200 therefore proximal NE Atlantic SST records have been used to estimate the shape of the UK MAAT curve. For 22-40 kyr the proximal SST record from ocean core BOFS (Biogeochemical Ocean Flux Study) 5K (Figure 3) was referenced; this site is located west of the Porcupine Seabight at a similar latitude to the southern UK (Maslin et al. 1995). This is believed to be a reasonably accurate estimate due to the proximity of the site, and similarity to the Davis et al. (2003) and Shakun et al. (2012) compilation curves from the 0-22 kyr interval (Figure 3). For BOFS 5K, both summer and winter absolute temperatures are reconstructed by using planktonic foraminiferal assemblage data and different transfer functions which all show similar trends (Figure 3).

Time interval 40-140 kyr BP

210 Finally, for the longer oldest time interval, the NE Atlantic SST reconstruction from ocean 211 core ODP 980 has been used (Figure 3), which is located in the Rockall Trough at a similar 212 latitude to the central UK (McManus et al. 1999). This record has some similarities to BOFS

$2135 \mathrm{~K}$, but is at a far lower temporal resolution and is therefore only applied to the older interval.

\section{Scaling the MAAT curve}

215 In order to scale the idealised MAAT curve (Figure 4 middle panel) modern MAAT is 216 applied as the Holocene average (maximum temperature), and the Annan and Hargreaves 217 (2013) global estimate of MAAT during the LGM (19-23 kyr BP) is used as a guide for the 218 minimum temperature, with a linear scaling of temperature between. The Annan \& 219 Hargreaves (2013) dataset is based on a combination of computer modelling and pollen 220 MAAT proxies, where northern England and Scotland localities are $12-20^{\circ} \mathrm{C}$ below present. 221 Therefore, the minimum MAAT for the Cairngorms during the LGM has been estimated as $22217^{\circ} \mathrm{C}$ below modern (present day) temperatures. This estimated temperature anomaly 223 of $-17^{\circ} \mathrm{C}$ below present day temperatures for the Cairngorm region can be compared against 
regional estimates. The average global estimate for the LGM fits reasonably well with the NE Atlantic SST records, which show $\sim 11^{\circ} \mathrm{C}$ offset between Holocene and LGM values at BOFS 5K (Maslin et al. 1995), and $\sim 8^{\circ} \mathrm{C}$ offset at ODP 980 (McManus et al. 1999). The anomaly is slightly greater than the SST estimates of the oceans surrounding the UK published by MARGO et al. (2009), which were based on a synthesis of global integrated fossil and geochemical proxies. It also fits well with pollen based reconstructions at $21 \mathrm{kyr}$ BP from central Europe (Bartlein et al. 2011) and NE France (Busschers et al. 2007), showing MAAT $\sim 10^{\circ} \mathrm{C}$ below present, and the pollen-based European regional reconstructions for the Younger Dryas (12-11 kyr) at $\sim 4^{\circ} \mathrm{C}$ below present (Davis et al. 2003).

\section{Effect of ice cover}

Due to the insulating capacity of ice sheets, the final land surface temperature estimates will differ from the estimated MAAT during periods of glacier ice cover. Hence, it is necessary to reconstruct the times at which the East Grampians were covered by glacier ice. This has been modelled by several studies (e.g. Siegert \& Dowdeswell 2004; Hubbard et al. 2009; Evans et al. 2009; Clark et al. 2012). The British Ice Sheet reconstructions of Hubbard et al. (2009) provide a series of time-slices with reconstructed ice sheet extent since $35 \mathrm{kyr}$ BP. To reconstruct the presence of an ice sheet in the older part of the record two scenarios have been modelled. A number of authors have presented evidence for glaciations during this older period (e.g. Clapperton 1997; Stoker \& Bradwell 2005; Stewart \& Lonergan 2011), so in the first scenario glacier ice is assumed in the period 35-120 kyr BP whenever the reconstructed temperature is at or below that during the period 12-35 kyr BP where Hubbard et al. (2009) modelled the presence of glacier ice in the East Grampians region. Thus, ice cover is assumed continuously from $110 \mathrm{kyr}$ to $12 \mathrm{kyr}$ BP. However, some authors dispute the presence of older ice cover (e.g. Westaway \& Younger, 2013) and so in the second scenario it is assumed the Cairngorm region is only covered by glacier ice during the period 37 to $12 \mathrm{kyr}$ BP.

Temperatures at the base of the Scottish ice sheet were discussed by Glasser \& Siegert (2002) and Hall \& Glasser (2003). Wet-based ice that is often found under thick ice in topographical troughs is warmer than dry-based ice frozen to its bed. Temperatures at the base of the ice will also be affected by the mean annual air temperature. Sliding at the base of ice sheets may be due to the pressure being close to the pressure melting point; a sufficiently high pressure that the ice melts even though its temperature is below $0^{\circ} \mathrm{C}$. Hall \& Glasser (2003) have shown that during basal freezing conditions, basal temperatures can range from $-12^{\circ} \mathrm{C}$ to $-6^{\circ} \mathrm{C}$ (absolute). However, when basal melting occurs, basal temperatures are more likely to be in 
the range of $-1^{\circ} \mathrm{C}$ to $+1^{\circ} \mathrm{C}$ (absolute). The results of Hall \& Glasser (2003) have been used to assign basal ice temperatures for the four heat flow borehole localities considered here. For the period 110-37 kyr BP a pre-glacial topography is assumed, whilst present-day topography is used for the period 37-12 kyr BP. The Mount Battock, Bennachie and Ballater boreholes are all in valleys, hence a basal ice temperature of $0^{\circ} \mathrm{C}$ is assumed for the period $110-37 \mathrm{kyr}$ $\mathrm{BP}$ and $+1^{\circ} \mathrm{C}$ (absolute) for 37-12 kyr BP. The Cairngorm borehole is situated at a higher elevation (616 m compared to 220 $\mathrm{m}$ for the other boreholes) and is on the upper slope of a valley. Assumed basal ice temperatures are therefore $-3^{\circ} \mathrm{C}$ (absolute) for the period 110-37 $\mathrm{kyr}$ BP and $-2^{\circ} \mathrm{C}$ (absolute) for 37-12 kyr BP. These surface temperature histories are shown in Figure 5.

Heat flow from each of the boreholes has been corrected for the surface temperature histories. There are two alternative corrections reflecting the two scenarios of continuous ice cover from 110-12 kyr BP (scenario 1) and ice cover only for the period 37-12 kyr BP (scenario 2). These corrections are listed in Table 1 and demonstrate that the palaeoclimate correction is large, approximately $24-28 \%$ of the raw (uncorrected) heat flow.

\section{Corrections for topography}

Heat flow is also affected by topography as heat will preferentially diffuse into valleys resulting in an over estimate of heat flow in valleys, but an underestimate on hills and mountains. As the heat flow boreholes in the East Grampians region were all in valley locations heat flow will have been over estimated. Wheildon et al. (1984) applied a topographic correction using an analytical three-dimensional treatment of topography, described by Bullard (1940), and the heat flow values quoted in the Introduction above include this correction. Westaway \& Younger (2013) also discussed topographic corrections and adapted a method by Lees (1910) for mountain ranges so that it could be applied to valley locations. In this method a $2 \mathrm{D}$ topographic profile perpendicular to the valley axis is fitted according to a mathematical form, referred to as a Lees Valley. From the fit, a series of parameters are obtained from which the temperature perturbation arising from the valley is easily calculated at any depth and location along the profile. From knowledge of thermal conductivity this can be converted to a perturbation to heat flow via equation (1). For the depth range 100-290 m Westaway \& Younger (2013) calculated a topographic heat flow correction of $-5.7 \mathrm{mWm}^{-2}$ for the Ballater borehole. The Lees Valley method has been applied here to Ballater for each of the intervals over which heat flow was calculated and the average for the depth range $140-280 \mathrm{~m}$ is $-5.8 \mathrm{mWm}^{-2}$. The value quoted by Wheildon et al. (1984) 
290 for Ballater is $-4.2 \mathrm{mWm}^{-2}$, which is in close agreement with those derived using the Lees

291 Valley method. Therefore heat flow topographic corrections for the Cairngorm, Mount 292 Battock and Bennachie boreholes have not been repeated using the Lees Valley method and 293 the corrections of Wheildon et al. (1984) are used. These are shown in Table 1 along with a 294 final corrected heat flow for each borehole.

\section{New insights into the geology and petrogenesis of the East Grampians Batholith}

296 All of the East Grampians intrusions have been re-mapped since the mid-1980s (British 297 Geological Survey 1989; 1992; 1993a,b; 1995a,b,c; 1996a,b; Harrison 1987; Thomas et al. 298 2004). The new maps and descriptions reveal aspects of their character and emplacement 299 history in considerably more detail than was known previously. A feature of all the intrusions 300 (and of the nearby Monadhliath intrusion, which is similar lithologically and also has HHP 301 character), is the sense of a complicated emplacement history. The two larger intrusions 302 (Cairngorm and Mount Battock) in particular display patterns indicating multi-phase 303 emplacement of magma batches that over time became smaller and increasingly scattered within the confines of the intrusion. Two-phase texture, caused when magma is emplaced forcefully into a nearly-solidified rock causing it to brecciate, is another relatively common feature of the East Grampians intrusions, providing further support for a complicated, multiphase emplacement history. This character may in part reflect the compositional similarity of the various batches of magma, which probably lacked the contrasts in density and viscosity that are believed to yield more ordered arrangements, such as concentric zoning, in some intrusions. However, the large number of discrete mappable units and their lack of spatial order contrast markedly with other well-characterised granite intrusions of broadly the same age in Scotland, which display simple, concentrically zoned patterns at outcrop; these include the Ben Rinnes, Lochnagar, and Peterhead plutons (Stephenson \& Gould 1995), the Fleet pluton (Stephens 1999) and the Ross of Mull pluton (Highton 1999).

It seems likely that HHP character, highly evolved magma compositions, disordered emplacement patterns, and fluid enrichment are related features in the four studied East

317 Grampians intrusions. The presently exposed surface through each one probably lies near to 318 (<2 km below) the former intrusion roof (Thomas et al. 2004), in a zone situated at the top of 319 the evolving magma system. Within this zone, multiple batches of highly fractionated, radiothermal granite magma were emplaced in rapid succession. Much of the magma fractionation may have occurred prior to emplacement, at deeper levels in the system, and there was probably little additional fractionation following emplacement. The radiothermal 
elements therefore may not be vertically fractionated within the zone exposed at outcrop.

324 This zone is likely to be of limited vertical extent - perhaps 1-2 km - and a vertical diminution in the concentration of radiothermal elements may only become apparent over a depth range of this size. Fluid exsolving from the magma (and perhaps also entering the system from adjacent country rocks) initially caused pervasive alteration of crystallised minerals (mainly feldspars), but became increasingly partitioned into discrete zones as the magma solidified. The Hill of Fare, Lochnagar, Glen Gairn and Peterhead intrusions crop out in the same E-W trending zone as the four intrusions studied in the Geothermal Energy programme, and a shared set of geochemical and petrological attributes (and similar age) led Stephens \& Halliday (1984) to propose that they all share a genetic relationship and therefore constitute a suite - the 'Cairngorm Suite'. Stephens \& Halliday (1984) did not include intrusions north of the Great Glen Fault in their study, but the Helmsdale intrusion and possibly one or two others in this region appear to share the same set of attributes and may be related genetically to the East Grampians intrusions. These other intrusions of the Cairngorm Suite have HP values in the range 2.2-4.1 $\mu \mathrm{Wm}^{-3}$ (Brown et al. 1982) and therefore lack the very high HP values of the four studied intrusions. They also lack evidence for fluid enrichment, and they have more organised emplacement patterns - the Lochnagar, Peterhead and Ben Rinnes intrusions are concentrically zoned at outcrop (Stephenson \& Gould 1995). These intrusions may therefore give an indication of what the Cairngorm, Mt Battock, Ballater and Bennachie intrusions are like at levels a few kilometres below their present outcrop.

Webb \& Brown (1984) showed that HP values calculated from surface samples were around 20-30\% lower than those in equivalent rocks collected from borehole cores, because uranium is easily leached in near-surface bedrock. The range of HP values for these other intrusions of the Cairngorm Suite rises to 2.6-4.9 $\mu \mathrm{Wm}^{-3}$ after a correction of $20 \%$ is applied to allow for inferred uranium leaching. The East Grampians granite intrusions have such highly evolved compositions that the nature of their source rocks has not been deduced with certainty. They display I-type characteristics (formed mainly from melted igneous rock), but were considered by Stephens \& Halliday (1984) to be transitional between I-type and A-type (formed from melted high-grade metamorphic rocks). If they are I-type, the intrusions may be vertically stratified, with granite at outcrop and progressively less evolved compositions (e.g. granodiorite, diorite and cumulate mafic rocks) at deeper levels. 
The palaeoclimate corrections clearly indicate that a substantial underestimation of heat flow has occurred by not considering the effect of past climate. The two scenarios of continuous ice cover from 110-12 kyr BP (scenario 1) and ice cover only for the period 37-12 kyr BP (scenario 2) have produced a very similar result. This is because at the shallow depths of the East Grampian boreholes, the main palaeoclimate influence is the warming that has taken place since the LGM during the last $18 \mathrm{kyr}$. The difference in the two climate scenarios occurs for the period prior to $37 \mathrm{kyr}$, which would have a greater influence on the palaeoclimate correction for heat flows calculated from greater depths. The palaeoclimate correction for each borehole has been taken as the mean of the two climate scenarios and these range from 20.7 to $17.9 \mathrm{mWm}^{-2}$. The Bennachie borehole yields the highest value, but also has the largest error due to the discrepancy in thermal conductivities between the upper and lower sections of the borehole. For the analysis at Bennachie three heat flow determinations were made in the interval 90-200 m and three in the interval 200-280 m. Hence, the upper part of the borehole generates a lower value of corrected heat flow (89.9 \pm $\left.2.1 \mathrm{~mW} \mathrm{~m}^{-2}\right)$ compared to the lower part $\left(111.9 \pm 1.4 \mathrm{~mW} \mathrm{~m}^{-2}\right)$. There is no discussion in Wheildon et al. (1984) as to the change in thermal conductivity, but the high values in the lower part of the borehole appear suspect. In Table 1 heat flows are listed for the average of the whole borehole and the average for the upper section. Overall, the measured heat flow from the four boreholes of the East Grampians shows a substantial increase over that previously reported as a result of correction for palaeoclimate. The percentage increases are 27\%, 29\%, 24\% and 18\% for the Cairngorm, Mount Battock, Ballater and Bennachie (upper section) boreholes respectively. Combining these borehole heat flows gives a mean revised heat flow for the East Grampians batholith of $86 \pm 7 \mathrm{mWm}^{-2}$, an increase of $25 \%$ over the previously reported values of Wheildon et al. (1984).

The gravity modelling of Rollin (1984; 2009) represented the granites as large volumes with steeply outward-dipping straight (or slightly convex) sides extending to considerable depth (9-13 km) with either a flat or curved base, modelled with a mean granite density of $2.62 \mathrm{Mg}$ $\mathrm{m}^{-3}$. This can be considered as the traditional view of how granites are intruded into the upper crust. This gravity modelling is at odds with the revised petrological evidence where it is expected that the East Grampians intrusions become increasingly mafic, and therefore denser, with depth. More recent published work (e.g. Cruden 1998; Petford et al. 2000; Taylor 2007) indicates that granites more commonly have a tabular form reflecting upward travel of magma through one or several near-vertical, narrow (1 - 50 m wide) conduits. Spreading-out 
of the magma at higher crustal levels results in thinner granite (a few kms thick) with potentially very thick granite over the feeder conduits. The Bouguer gravity anomaly at the

390 Cairngorm and Ballater borehole sites is $-46 \mathrm{mGal}$ and is -28 and $-38 \mathrm{mGal}$ at the Bennachie and Mount Battock borehole sites respectively. Assuming a tabular space form for the East

392 Grampians batholith this may indicate a central, west-east orientated conduit (beneath

393 Cairngorm and Ballater) and thinner tabular lobes to the north and south (beneath Bennachie and Mount Battock). The revised heat flow value for Mount Battock is the lowest, possibly reflecting thinner granite, although the heat flow values for Cairngorm, Ballater and Bennachie are virtually the same.

Sub-surface temperature profiles, based on the revised heat flow determinations, and taking into consideration the nature of the East Grampians batholith, have been made. It is assumed that the Cairngorm, Mount Battock, Ballater and Bennachie intrusions are part of the roof zone of the evolved magma system and, due to vertical fractionation, the concentration of radiothermal elements diminishes with depth. Other intrusions of the Cairngorm suite may give an indication of reduced HP values at depth within the East Grampians batholith. From studies of continental heat flow it has been observed that there is a linear relationship between the heat production at the surface, $A_{0}\left(\mu \mathrm{W} \mathrm{m}{ }^{-3}\right)$, and the surface heat flow, $q_{0}$ $\left(\mathrm{mWm}^{-2}\right)$ (Birch et al, 1968; Roy et al, 1968) i.e.

$$
\mathrm{q}_{0}=\mathrm{q}^{*}+\mathrm{A}_{0} \mathrm{D}
$$

407 where $\mathrm{q}^{*}$ is the basal or lower crust/mantle heat flow $\left(\mathrm{mWm}^{-2}\right)$ and $\mathrm{D}$, which has a dimension 408 of length, represents a depth of radioactive enrichment within the upper crust. Solutions for calculating the subsurface temperature are given by Wheildon et al. (1981) and Wheildon \& Rollin (1986). These take into account the decrease of thermal conductivity with increasing temperature, which will occur with increasing depth, i.e.

$$
\lambda_{z}=\frac{\lambda_{0} a \prime}{\left(b^{\prime}+T_{z}\right)}
$$

413 where $\lambda_{\mathrm{z}}\left(\mathrm{W} \mathrm{m} \mathrm{m}^{-1} \mathrm{~K}^{-1}\right)$ is the thermal conductivity at depth $\mathrm{z}(\mathrm{km}), \lambda_{0}\left(\mathrm{~W} \mathrm{~m}^{-1} \mathrm{~K}^{-1}\right)$ is the 414 surface thermal conductivity, $\mathrm{T}_{\mathrm{z}}\left({ }^{\circ} \mathrm{C}\right)$ is temperature at depth $\mathrm{z}, \mathrm{b}^{\prime}$ is an empirical constant, 415 with units of ${ }^{\circ} \mathrm{C}$, quoted by Wheildon \& Rollin (1986) as 823.33 and a $=\mathrm{b}^{\prime}+\mathrm{T}_{0}$ (where $\mathrm{T}_{0}$ is 416 the surface temperature in ${ }^{\circ} \mathrm{C}$ ). The vertical temperature distribution is given by Wheildon \& 417 Rollin, (1986) as,

$$
T_{z}=a^{\prime} e^{\frac{\left(q_{0} z-f(z)\right)}{a^{\prime} \lambda_{0}}}-b^{\prime}
$$


419 Where for an exponential decrease of heat production with depth, $\mathrm{f}(\mathrm{z})$ in equation (7) has the 420 form,

$$
f(z)=A_{0} D\left[z-D\left(1-e^{\frac{-z}{D}}\right)\right]
$$

422

423

424

425

426

427

428

429

430

431

432

433

434

435

436

437

438

439

440

441

442

443

444

445

446

447

448

449

In this case $D$ is the range of depth over which the heat production decreases to 1/e (0.37) of its surface value and has been assigned a value of $4 \mathrm{~km}$. Predicted sub-surface temperatures incorporating the revised heat flows are tabulated in Table 2 along with $\lambda_{0}$ and $T_{0}$ for each borehole (note that heat production data, $\mathrm{A}_{0}$, are given in Table 1 ). A graphical representation of the sub-surface temperatures is shown in Figure 6. Two predictions are shown for Bennachie, the first (small dashed line) is based on the heat flow of $100.9 \mathrm{mWm}^{-2}$ calculated from the whole depth of the borehole and the second (large dashed line) on the heat flow of $89.9 \mathrm{mWm}^{-2}$ calculated from the upper section of the borehole. For the East Grampians batholith as a whole the predicted temperature at $5 \mathrm{~km}$ depth is $129^{\circ} \mathrm{C}$ and at $7 \mathrm{~km}$ depth it is $176{ }^{\circ} \mathrm{C}$, where these mean temperatures have excluded the heat flow calculated from the lower section of the Bennachie borehole where the thermal conductivities appear suspect. The predicted temperatures are dependent on the depth value D. For instance, if $D=7 \mathrm{~km}$ then the equivalent mean temperatures at $5 \mathrm{~km}$ and $7 \mathrm{~km}$ depth are $126{ }^{\circ} \mathrm{C}$ and $168{ }^{\circ} \mathrm{C}$ respectively. A value of $\mathrm{D}=4 \mathrm{~km}$ is preferred based on the geological mapping evidence presented above that the HHP character of the granite is likely to be confined to a relatively narrow upper zone of the intrusions.

Westaway (2009) and Westaway \& Bridgland (2014) also present a solution to the temperature distribution with depth assuming heat production decreases exponentially with depth, but with constant thermal conductivity, i.e.

$$
T_{z}=T_{0}+\frac{q^{*} z}{\lambda_{0}}+\frac{A_{0} D^{2}}{\lambda_{0}}\left(1-e^{\frac{-z}{D}}\right)
$$

With a value of $\mathrm{D}=4 \mathrm{~km}$ and with the same parameters as used above, sub-surface temperature predictions based on equation (9) are also tabulated in Table 2 and shown in Figure 7. The result is a set of slightly reduced geotherms $\left(-8{ }^{\circ} \mathrm{C}\right.$ at $5 \mathrm{~km}$ and $-15^{\circ} \mathrm{C}$ at $7 \mathrm{~km}$ depth) that illustrates the importance of considering the effect of increasing temperature on thermal conductivity.

The revised temperatures of $129{ }^{\circ} \mathrm{C}$ and $176{ }^{\circ} \mathrm{C}$ at $5 \mathrm{~km}$ and $7 \mathrm{~km}$ respectively, compare to temperatures of $92{ }^{\circ} \mathrm{C}$ at $5 \mathrm{~km}$ depth and $118{ }^{\circ} \mathrm{C}$ at $7 \mathrm{~km}$ depth predicted by Wheildon et al. 1984, corresponding to percentage increases of $40 \%$ at $5 \mathrm{~km}$ depth and $49 \%$ at $7 \mathrm{~km}$ depth. 
450 These temperatures are lower than expected at similar depths in the Cornubian batholith of 451 Cornwall where temperatures of $182{ }^{\circ} \mathrm{C}$ at $5 \mathrm{~km}$ depth and $258{ }^{\circ} \mathrm{C}$ at $7 \mathrm{~km}$ depth were predicted by Downing \& Gray (1986a). However, they do indicate a substantially increased resource over that originally predicted for the East Grampians batholith and suggest that power generation could be possible from boreholes drilled to depths greater than $5 \mathrm{~km}$. In addition, the geothermal resource may be accessible as hot water (direct use geothermal). Calcite-cemented breccia, quartz-calcite veins and calcite veins were all described from the cores taken in the heat flow boreholes (Webb \& Brown 1984; Webb et al. 1985) raising the possibility that there are networks of transmissive fractures at depth from where the calcite has dissolved. Manning et al. (2007) measured a fracture permeability of $1.68 \times 10^{-10} \mathrm{~m}^{2}$ within the North Pennine Batholith (Weardale granite) which is the highest measured permeability for a granite within the UK. Although there is no evidence to indicate a fracture permeability of this magnitude within the East Grampians, with predicted temperatures of 58 ${ }^{\circ} \mathrm{C}$ at $2 \mathrm{~km}$ depth a borehole targeted to intersect a fracture zone could provide a direct use resource for communities within the Cairngorm region.

\section{Conclusions}

466 A rigorous correction for the effects of palaeoclimate on heat flow has been applied to the 467 East Grampians batholith. This has resulted in an increase of 25\% over previously reported values to $86 \pm 7 \mathrm{mWm}^{-2}$. Two scenarios have been followed for the surface temperature history in the Cairngorm region during the last glacial-interglacial cycle due to uncertainty in the extent of ice cover for the period prior to $37 \mathrm{kyr}$ BP. These two scenarios made little difference to the correction demonstrating that in the depth range $100-300 \mathrm{~m}$ it is warming since the LGM that has been the major influence on perturbing subsurface temperatures. Recent mapping suggests that the outcropping granites of the East Grampians batholith lie near the surface of a highly evolved magma system. Evidence from other outcropping granites that are probably representative of the Cairngorm, Mount Battock,

476 Ballater and Bennachie intrusions at a few kilometres depth supports the hypothesis that heat 477 production decreases with depth as the rock becomes progressively less siliceous. The coincident, large Bouguer gravity anomaly low has been previously modelled as granite extending to great depth. More recent work on granite emplacement suggests that granite intrusions are more likely to be tabular in form with deep seated, semi-vertical feeder 
outcrop with more mafic (and hence denser) rocks at depth. It is recommended that a new 3D gravity model of the East Grampians batholith should be produced.

Modelling of sub-surface temperatures that take account of the decrease of heat production and thermal conductivity with depth suggest a temperature of $129{ }^{\circ} \mathrm{C}$ at $5 \mathrm{~km}$ depth and 176 ${ }^{\circ} \mathrm{C}$ at $7 \mathrm{~km}$ depth for the East Grampians batholith, increases of $40 \%$ and $49 \%$ respectively compared to previous estimates. Although these temperatures are currently at the lower end of viability for EGS they indicate that there is a considerable geothermal resource within the batholith. Hydrothermal alteration within the granite indicates the possibility of transmissive fractures at depth that might be exploitable for direct geothermal heat use.

\section{Acknowledgements}

This paper is published by permission of the Executive Director of the British Geological Survey (NERC).

ANNAN J D AND HARgreaves J C. 2013. A new global reconstruction of temperature changes at the Last Glacial Maximum. Climate of the Past, 9, 367-376.

Bartlein, P, Harrison, S, Brewer, S, Connor, S, Davis, B, Gajewski, K, Guiot, J, Harrison-Prentice, T, Henderson, A, Peyron, O, Prentice, I C, Scholze, M, Seppa, H, Shuman, B, Sugita, S, Thompson, R S, Viau, A E, Williams, J, AND WU, H. 2011. Pollen-based continental climate reconstructions at 6 and 21 ka: a global synthesis, Climate Dynamics, 37, 775-802.

BATCHELOR, A S. 1987. Development of Hot-Dry-Rock geothermal systems in the UK. Thermal Power, IEE Proceedings, 134A(5), 371-380.

BEARDSMORE, G R AND CULL, J R. 2001. Crustal heat flow: a guide to measurement and modelling. Cambridge: Cambridge University Press.

BECK, A E. 1977. Climatically perturbed temperature gradients and their effect on regional and continental heat-flow means. Tectonophysics, 41, 17-39.

BENFIELD, A E. 1939. Terrestrial heat flow in Great Britain. Proceedings of the Royal Society, 173A, 430-450.

BIRCH, F. 1948. The effects of Pleistocene climatic variations upon geothermal gradients. American Journal of Science, 246, 729-760.

Birch, F, Roy, R F AND DeCKER, E R. 1968. Heat flow and thermal history in New England and New York. 437-451 in Studies in Appalachian Geology, AN-ZeN, E (ed), New York: Wiley Interscience.

British Geological Survey. 1989. Braemar. Scotland Sheet 65WE. Solid Geology. 1:50 000. British Geological Survey, Keyworth, Nottingham.

British Geological Survey. 1992. Inverurie. Scotland Sheet 76E. Solid Geology. 1:50 000. British Geological Survey, Keyworth, Nottingham. 

Geological Survey, Keyworth, Nottingham.

British Geological Survey. 1993b. Aviemore. Scotland Sheet 74E. Solid Geology. 1:50 000. British Geological Survey, Keyworth, Nottingham.

British Geological Survey. 1995a. Aboyne. Scotland Sheet 66W. Solid Geology. 1:50 000. British Geological Survey, Keyworth, Nottingham.

British Geological Survey. 1995b. Ballater. Scotland Sheet 65E. Solid Geology. 1:50 000. British Geological Survey, Keyworth, Nottingham.

British Geological Survey. 1995c. Glenbuchat. Scotland Sheet 75E. Solid Geology. 1:50 000. British Geological Survey, Keyworth, Nottingham.

British Geological Survey. 1996a. Banchory. Scotland Sheet 66E. Solid and Drift Geology. 1:50 000. British Geological Survey, Keyworth, Nottingham.

British GeOlogical Survey. 1996b. Glenlivet. Scotland Sheet 75W. Solid Geology. 1:50 000. British Geological Survey, Keyworth, Nottingham.

BRown, G C, WebB, P C, LeE, M K, WheILDOn, J AND CASSIDY, J. 1982. Development of HDR reconnaissance in the United Kingdom. In: Proceedings International Conference on Geothermal Energy, Florence, Italy, BHRA Fluid Engineering, Cranfield, England, 353-367.

Bullard, E C. 1939. Heat flow in South Africa. Proceedings of the Royal Society of London, 173A, 428-450.

BULLARD, E C. 1940. The disturbance of the temperature gradient in the earth's crust by inequalities of height. Monthly Notices of the Royal Astronomical Society Geophysical Supplement, No 4, 360-362.

Busschers, F S, Kasse, C, van Balen, R T, Vandenberghe, J, Cohen, K M, Weerts H J T, Wallinga, J, Johns, C, Cleveringa, P And Bunnick, F P M. 2007. Late Pleistocene evolution of the Rhine-Meuse system in the southern North Sea basin: Imprints of climate change, sea-level oscillation and glacioisostacy. Quaternary Science Reviews, 26, 3216-3248.

540 Carslaw, H A and Jaeger J C. 1959. Conduction of heat in solids. $2^{\text {nd }}$ ed. Oxford: Oxford University Press.

Clapperton, C M. 1997. Greenland ice cores and North Atlantic sediments: implications for the last glaciation in Scotland. In: Gordon, J.E. (Ed.), Reflections on the Ice Age in Scotland. Scottish Natural Heritage, Edinburgh, 45-58.

Clark, C D, Hughes, A L C, GreEnwood, S L, Jordan, C, SeJrup, H P. 2012. Pattern and timing of retreat of the last British-Irish Ice Sheet. Quaternary Science Reviews, 44, 112-146.

CRAIN, I K. 1968. The glacial effect and the significance of continental terrestrial heat flow measurements. Earth and Planetary Science Letters, 4, 69-72. 853-862. 

Europe during the Holocene reconstructed from pollen data. Quaternary Science Reviews, 22, 1701-1716.

552

553

554

555

556

557

558

559

560

561

562

563

564

565

566

567

568

569

570

571

572

573

574

575

576

577

578

579

580

581

582

583

Downing, R. A. AND GRAY, D. A. (eds.) 1986a. Geothermal Energy - The potential in the United Kingdom. HMSO, London.

Downing, R. A. AND GRAY, D. A. 1986b. Geothermal resources of the United Kingdom. Journal of the Geological Society, London, 143, 499-507.

Evans, D J A, Livingstone, S J, Vieli, A, O’Cofaigh, C. 2009. The palaeoglaciology of the central sector of the British and Irish Ice Sheet: reconciling glacial geomorphology and preliminary ice sheet modelling. Quaternary Science Reviews, 28,739-757.

GLASSER, N F AND SIEGERT, M J. 2002. Calculating basal temperatures in ice sheets: an Excel spreadsheet method. Earth Surface Processes and Landforms, 27, 673-680.

HALL, A M AND GLASSER, N F. 2003. Reconstructing the basal thermal regime of an ice stream in a landscape of selective linear erosion: Glen Avon, Cairngorm Mountains, Scotland. Boreas, 32, 191-207.

HARRISON, T J. 1987. The evolution of the Eastern Grampian Granites. Unpublished PhD thesis, University of Aberdeen.

Highton, A J. 1999. Cnoc Mor to Rubh’ Ardlanish. 417-421 in Geological Conservation Review Series Caledonian Igneous Rocks of Great Britain. Stephenson D et al. (eds). (Peterborough: Joint Nature Conservation Committee.)

Hubbard, A, Bradwell, T, Golledge, N, Hall, A, Patton, H, Sugden, D, Cooper, R, and Stoker, M. 2009. Dynamic cycles, ice streams and their impact on the extent, chronology and deglaciation of the British-Irish ice sheet. Quaternary Science Reviews, 28, 758-776.

Jessop, A M. 1971. The Distribution of Glacial Perturbation of Heat Flow in Canada. Canadian Journal of Earth Sciences, 8, 162-166.

LEE, M K. 1984. Analysis of geophysical logs from the Shap, Skiddaw, Cairngorm, Ballater, Mount Battock and Bennachie heat flow boreholes. Report in series: Investigation of the Geothermal Potential of the UK. British Geological Survey.

Lee, M K, Wheildon, J, Webb, P C, Brown, G C, Rollin, K E, Crook, C N, Smith, I F, King, G and ThomasBETTS, A. 1984. Hot dry rock prospects in Caledonian Granites: evaluation of results from the BGS-ICOU research programme (1981-1984). Report in series: Investigation of the Geothermal Potential of the UK. British Geological Survey.

Lee, M K, Brown, G C, WebB, P C, Wheildon, J And Rollin, K E. 1987. Heat flow, heat production and thermo-tectonic setting in mainland UK. Journal of the Geological Society,London, 144, 35-42.

LEES, C H. 1910. On the shapes of isogeotherms under mountain ranges in radioactive districts. Proceedings of the Royal Society of London, 83A, 339-434. 
Manning, D A C, Younger, P, Smith, F W, Jones, J M Dufton, D J And Diskin, S. 2007. A deep geothermal exploration well at Eastgate, Weardale, UK: a novel exploration concept for low-enthalpy resources. Journal of the Geological Society, London, 164, 371-382.

MARGO Project Members, 2009. Constraints on the magnitude and patterns of ocean cooling at the Last Glacial Maximum. Nature Geoscience, 2, 127-132, doi:10.1038/NGEO411.

Maslin, M A, Shackleton, N J And Pflaumann U. 1995. Surface water temperature, salinity, and density changes in the northeast Atlantic during the last 45,000 years: Heinrich events, deep water formation, and climatic rebounds. Paleoceanography, 10, 527-544, doi:10.1029/94PA03040.

McManus, J F, Oppo, D W And Cullen, J L. 1999. A 0.5-Million-Year Record of Millennial-Scale Climate Variability in the North Atlantic. Science, 283, 971-975.

MIT (Massachusettes Institute of Technology). 2006. The Future of Geothermal Energy: Impact of Enhanced Geothermal Systems (EGS) on the United States in the 21st Century. http://geothermal.inel.gov.

North Greenland Ice Core Project members, 2004. High-resolution record of Northern Hemisphere climate extending into the last interglacial period. Nature, 431, 147-151.

Petford, N, Cruden, A R, McCaffrey, K J W and Vigneresse J-L. 2000. Granite magma formation, transport and emplacement in the Earth’s crust. Nature, 408, 669-673.

Richards, H G, Parker, R H and Green, A S P. 1994. The performance and characteristics of the experimental hot dry rock geothermal reservoir at Rosemanowes, Cornwall (1985-1988). Geothermics, 23, 73-109.

RoLLIN, K E. 1982. A review of data relating to hot dry rock and selection of targets for detailed study. Report in series: Investigation of the Geothermal Potential of the UK. British Geological Survey.

RoLLIN, K E. 1984. Gravity modelling of the Eastern Highlands Granites in relation to heat flow studies. Report in series: Investigation of the Geothermal Potential of the UK. British Geological Survey.

RoLLIN, K E. 2009. Regional Geophysics of Northern Scotland. Version 1.0 on CD-ROM. British Geological Survey, Keyworth, Nottingham.

ROY, R F, BlACKWELL, D D AND BIRCH, F. 1968. Heat generation of plutonic rocks and continental heat flow provinces. Earth and Planetary Science Letters, 5, 1-12.

Shakun, J D, Clark, P U, He, F, Marcott, S A, Mix, A C, Liu, Z, Otto-Bliesner, B, Schmittner, A And BARD, E. 2012. Global warming preceded by increasing carbon dioxide concentrations during the last deglaciation. Nature, 484, 49-54.

SIEGERT, M J AND DOWDESWELL, J A. 2004. Numerical reconstructions of the Eurasian Ice Sheet and climate during the Late Weichselian. Quaternary Science Reviews, 23, 1273-1283.

StePhens, W E. 1999. Clatteringshaws Dam quarry. 456-459 in Geological Conservation Review Series Caledonian Igneous Rocks of Great Britain. Stephenson D et al. (eds). (Peterborough: Joint Nature Conservation Committee.) 
Stephens, W E AND Halliday, A N. 1984. Geochemical contrasts between late Caledonian granitoid intrusions of northern, central and southern Scotland. Transactions of the Royal Society of Edinburgh: Earth Sciences, 75, 259-273.

622 StePhenson, D. and Gould, D. 1995. British regional geology: the Grampian Highlands (4 ${ }^{\text {th }}$ edition). 623 (London: HMSO for the British Geological Survey.)

624 Stewart, M A AND Lonergan, L, 2011. Seven glacial cycles in the middle-late Pleistocene of northwest 625 Europe: Geomorphic evidence from buried tunnel valleys. Geology, 39, 283-286.

626

627

628

630

StOKER, M S AND BRADWELl, T. 2005. The Minch palaeo-ice stream, NW sector of the British-Irish Ice Sheet. Journal of the Geological Society, London, 162, 425-428.

TAYLOR, G K. 2007. Intrusion shapes in the Cornubian Batholith: new perspectives from gravity modelling. Journal of the Geological Society, London, 164, 525-528.

Thomas, C W, Gillespie, M R, Jordan , C J and Hall, A M. 2004. Geological structure and landscape of the Cairngorm Mountains. Scottish Natural Heritage Commissioned Report No. 064 (ROAME No. F00AC103).

WEBB, P C AND BROWN, G C. 1984. The Eastern Highlands granites: heat production and related geochemistry. Report in series: Investigation of the Geothermal Potential of the UK. British Geological Survey.

Webb, P C, Tindle, A G, Barritt, S D, Brown, G C And Miller, J F. 1985. Radiothermal granites of the United Kingdom: comparison of fractionation patterns and variation of heat production for selected granites. 409-424 in High heat production (HHP) granites, hydrothermal circulation and ore genesis. (The Institution of Mining and Metallurgy.)

WestAWAY, R. 2009. Quaternary uplift of northern England. Global and Planetary Change, 68, 357-382.

WESTAWAY, R AND BRIDGLAND D R. 2014. Relation between alternations of uplift and subsidence revealed by Late Cenozoic fluvial sequences and physical properties of the continental crust. Boreas, 43, 505-527.

WestawAy, R AND Younger, P L. 2013. Accounting for palaeoclimate and topography: A rigorous approach to correction of the British geothermal dataset. Geothermics, 48, 31-51.

Wheildon, J, King, G, Crook, C N And Thomas-BetTs, A. 1984. The Eastern Highlands granites: heat flow, heat production and model studies. Report in series: Investigation of the Geothermal Potential of the UK. British Geological Survey.

Wheildon, J, Francis, M F, Ellis, J R L And Thomas-BetTs, A. 1981. Investigation of the south-west England thermal anomaly zone. Report EUR 7276EN. (Brussels: CEC).

Wheildon, J And Rollin, K E. 1986. Heat Flow. 8-20 in Geothermal Energy - The potential in the United Kingdom, DOWNING, R. A. AND GRAY, D. A. (eds.) 1986. HMSO, London.

Younger, P L, GLuYAS, J G And STEPhens, W E. 2012. Development of deep geothermal energy resources in the UK. Institute of Civil Engineers Proceedings, 165 (EN1), 19-32. 
Figure 1. Distribution of granite within the crust of Scotland based on surface exposure and interpretations of gravity data. Heat production (in units of $\mu \mathrm{Wm}^{-3}$ ) are shown for intrusions where values greater than $3.5 \mu \mathrm{Wm}^{-3}$ have been measured.

Figure 2. Shaded relief image, illuminated from the north, of the Bouguer gravity anomaly over the East Grampians batholith, based on gravity data from the British Geological Survey national gravity databank. The outlines of outcropping granites are shown in red and the locations of the four heat flow boreholes are indicated by white crosses.

Figure 3. Selected temperature proxy records used to construct the average temperature trends over the UK during the past $140 \mathrm{kyr}$. References from top to bottom: A) Davis et al. (2003); B) Shakun at el. (2012); C) Maslin et al. (1995); D) McManus et al. (1999). SST is sea surface temperature and G-IG range is glacial-interglacial range.

Figure 4. The reconstructed UK temperature trend for the last $120 \mathrm{kyr}$ (B) scaled to the temperature at the Cairngorm latitude, aside the appended data used from several sources and regions to create the record (A; see also Figure 3). Ice core temperature proxy shown for comparison (C; North Greenland Ice Core Project members, 2004).

Figure 5. a) Surface temperature history for scenario 1 where continuous ice cover has been assumed for the period 110-12 kyr BP. The solid line is for Cairngorm and where this differs for Mount Battock, Bennachie and Ballater it is shown by the dashed line. b) Surface temperature history for scenario 2 where ice cover has been assumed for the period 37-12 kyr BP only. The solid line is for Cairngorm and where this differs for Mount Battock, Bennachie and Ballater it is shown by the dashed line.

Figure 6. Predicted sub-surface temperatures, based on the revised heat flow estimates, assuming heat production decreases exponentially with depth. A) Thermal conductivity decreases with temperature and B) thermal conductivity is assumed to be constant. In (A), the revised mean temperatures of $129^{\circ} \mathrm{C}$ at $5 \mathrm{~km}$ depth and $176{ }^{\circ} \mathrm{C}$ at $7 \mathrm{~km}$ depth are displayed as stars. Note that two predictions are shown for Bennachie, where the solid line uses heat flow calculated from the whole borehole and the dashed line from the upper section only.

Table 1. Tabulated values of heat production, uncorrected heat flow and corrections to heat flow with a final value of corrected heat flow for the East Grampians heat flow boreholes. The palaeoclimate correction scenarios and the two Bennachie borehole options are explained in the text. Note that the heat production data are from Webb \& Brown (1984) and the topographic correction is taken from Wheildon et al. (1984).

Table 2. Predicted temperatures at depth arising from the revised heat flow estimates. Heat production is assumed to decrease with depth exponentially for two cases. In the first, the temperature dependence of thermal conductivity is taken into account and in the second, it is assumed to be constant. 


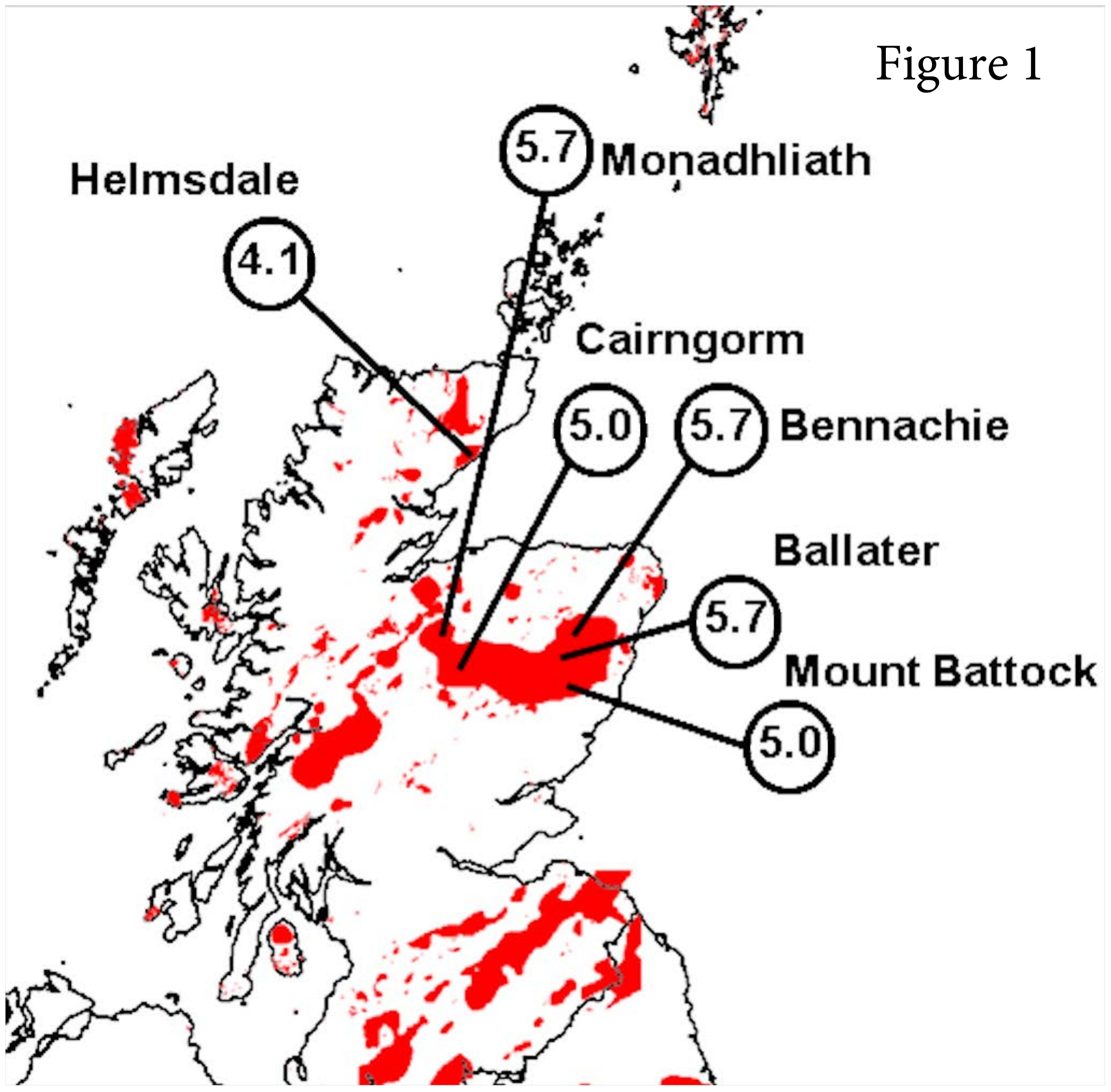




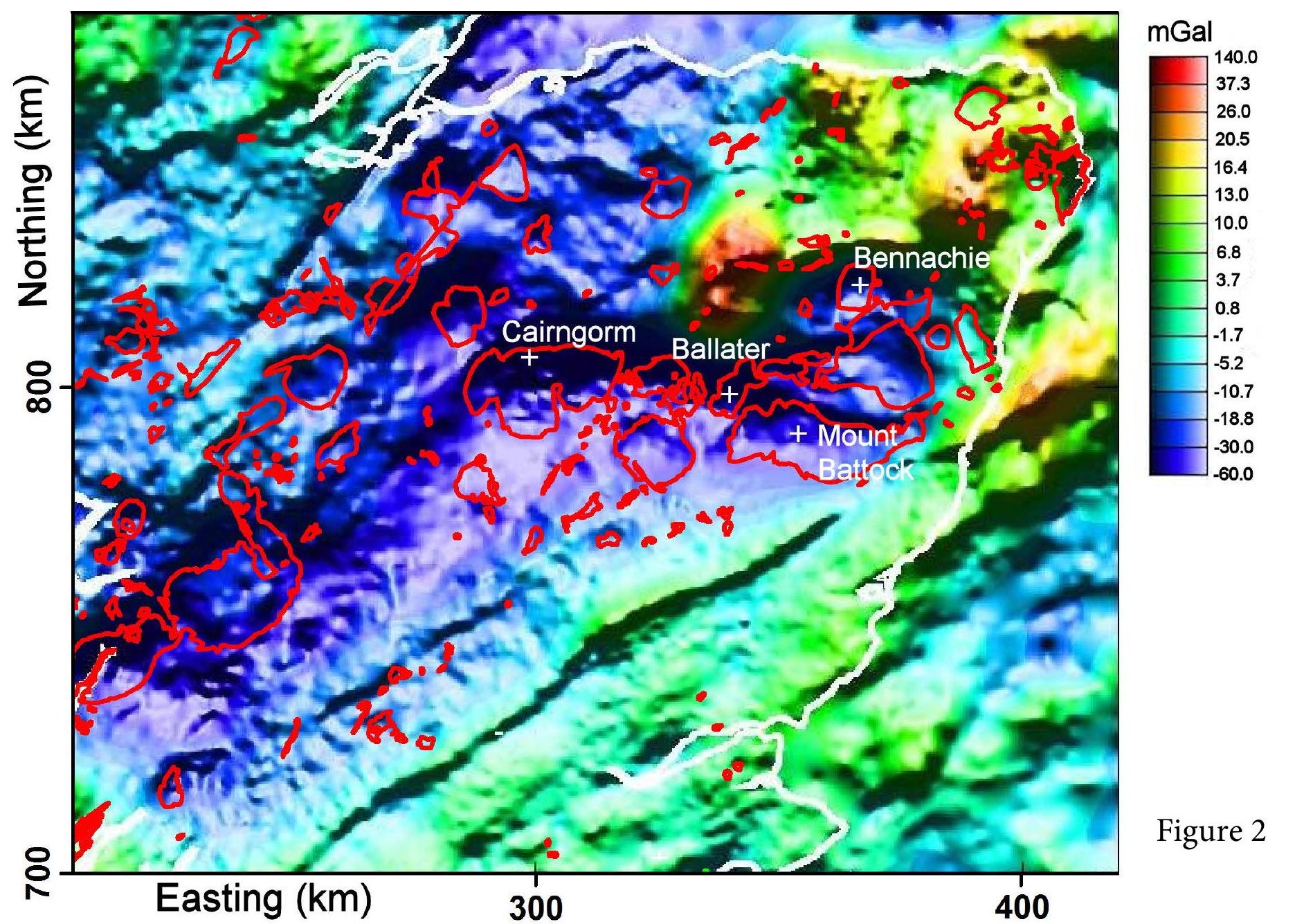


Figure 3

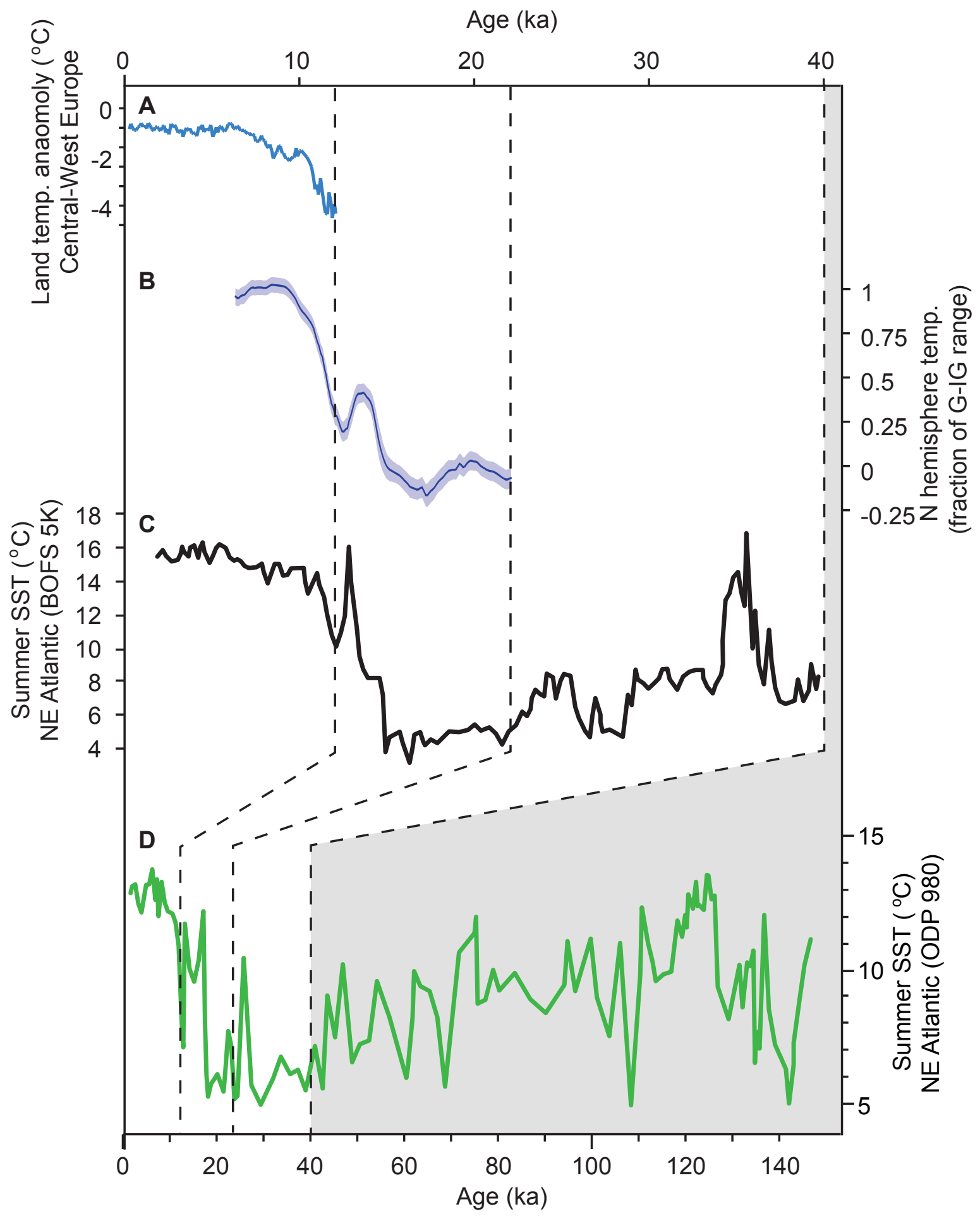


Figure 4

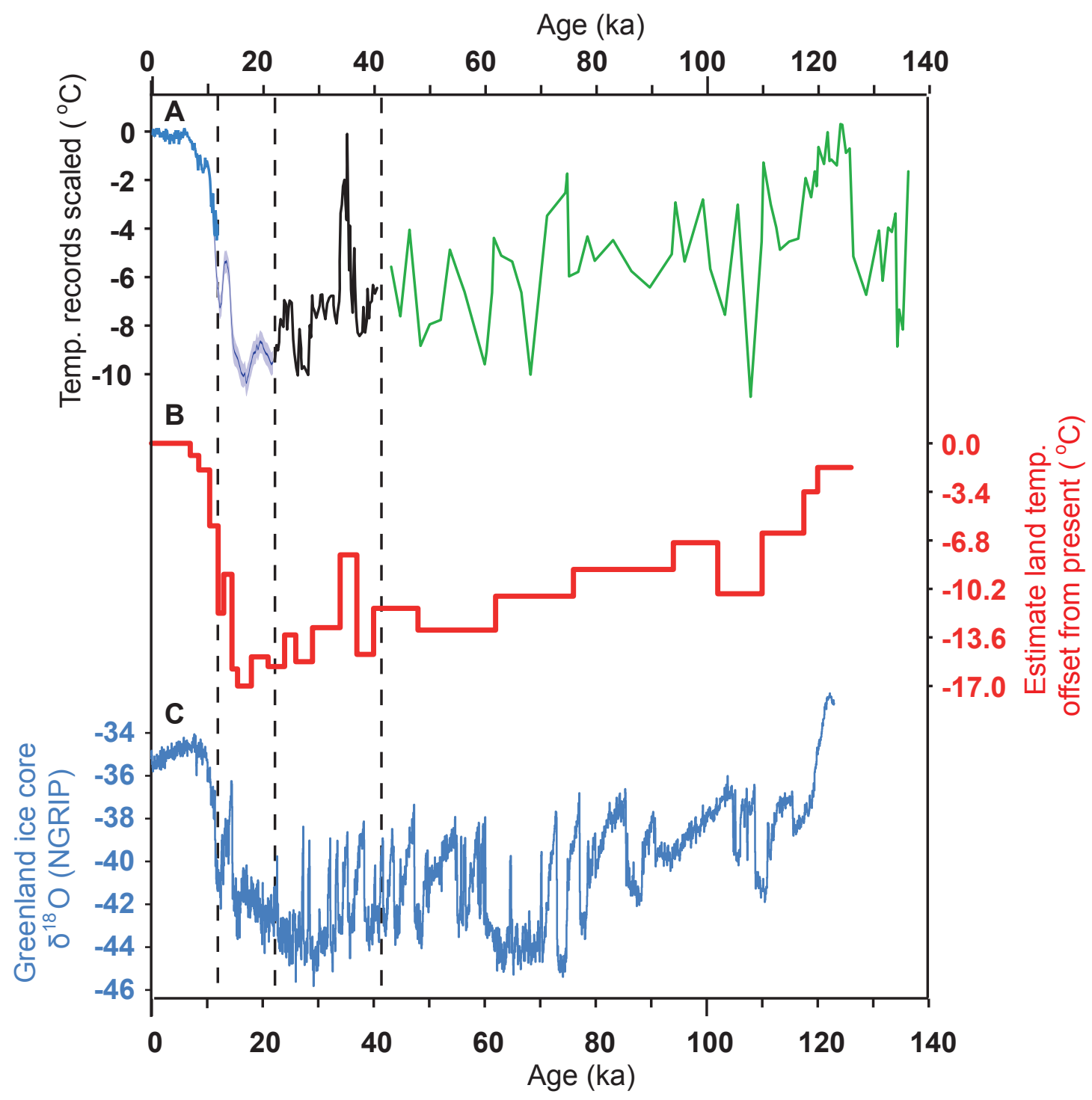


Figure 5a 
Figure $5 b$

$\ldots \ldots$ 
Table 1

\begin{tabular}{|c|c|c|c|c|c|c|c|}
\hline \multirow[t]{2}{*}{ Borehole } & \multirow{2}{*}{ 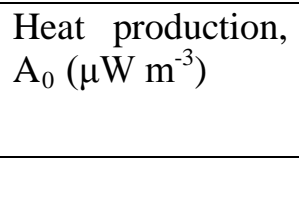 } & \multirow{2}{*}{$\begin{array}{l}\text { Uncorrected heat } \\
\text { flow }\left(\mathrm{mW} \mathrm{m}^{-2}\right)\end{array}$} & \multicolumn{3}{|c|}{ Palaeoclimate correction $\left(\mathrm{mW} \mathrm{m}^{-2}\right)$} & \multirow{2}{*}{$\begin{array}{l}\text { Topographic } \\
\text { correction } \\
\left(\mathrm{mW} \mathrm{m}^{-2}\right)\end{array}$} & \multirow{2}{*}{$\begin{array}{l}\text { Corrected heat flow, } \\
\mathrm{q}_{0}\left(\mathrm{~mW} \mathrm{~m}^{-2}\right)\end{array}$} \\
\hline & & & Scenario 1 & Scenario 2 & Mean & & \\
\hline Cairngorm & 7.3 & $71.3 \pm 2.8$ & $19.6 \pm 0.5$ & $21.0 \pm 0.4$ & $20.3 \pm 0.5$ & -2.7 & $88.9 \pm 2.8$ \\
\hline Mount Battock & 4.8 & $65.0 \pm 2.2$ & $17.4 \pm 0.4$ & $19.1 \pm 0.4$ & $18.2 \pm 0.4$ & -6.9 & $76.3 \pm 2.2$ \\
\hline Ballater & 6.8 & $74.1 \pm 3.4$ & $16.8 \pm 1.3$ & $19.0 \pm 0.8$ & $17.9 \pm 1.1$ & -4.2 & $87.8 \pm 3.6$ \\
\hline $\begin{array}{l}\text { Bennachie } \\
\text { (whole borehole) }\end{array}$ & 7.0 & $85.8 \pm 13.2$ & $19.6 \pm 1.8$ & $21.7 \pm 1.7$ & $20.7 \pm 1.7$ & -5.6 & $100.9 \pm 13.3$ \\
\hline $\begin{array}{l}\text { Bennachie } \\
\text { borehole) }\end{array}$ & 7.0 & $76.1 \pm 2.1$ & $18.3 \pm 0.4$ & $20.4 \pm 0.4$ & $19.4 \pm 0.4$ & -5.6 & $89.9 \pm 2.1$ \\
\hline
\end{tabular}

Table 2

\begin{tabular}{|c|c|c|c|c|c|c|}
\hline \multirow[t]{2}{*}{ Borehole } & \multirow{2}{*}{$\begin{array}{l}\text { Surface } \\
\text { temperature, } \\
\mathrm{T}_{0}\left({ }^{\circ} \mathrm{C}\right)\end{array}$} & \multirow{2}{*}{$\begin{array}{l}\text { Surface thermal } \\
\text { conductivity, } \lambda_{0} \\
\left(\mathrm{~W} \mathrm{~m} \mathrm{~m}^{-1} \mathrm{~K}^{-1}\right)\end{array}$} & \multicolumn{2}{|c|}{ Predicted temperature at $5 \mathrm{~km}$ depth $\left({ }^{\circ} \mathrm{C}\right)$} & \multicolumn{2}{|c|}{ Predicted temperature at $7 \mathrm{~km}$ depth $\left({ }^{\circ} \mathrm{C}\right)$} \\
\hline & & & $\begin{array}{l}\text { Temperature dependent } \\
\text { thermal conductivity }\end{array}$ & $\begin{array}{l}\text { Constant thermal } \\
\text { conductivity }\end{array}$ & $\begin{array}{l}\text { Temperature dependent } \\
\text { thermal conductivity }\end{array}$ & $\begin{array}{l}\text { Constant thermal } \\
\text { conductivity }\end{array}$ \\
\hline Cairngorm & 5.8 & 3.5 & 122 & 115 & 167 & 153 \\
\hline Mount Battock & 8.2 & 3.0 & 130 & 122 & 178 & 163 \\
\hline Ballater & 8.2 & 3.2 & 136 & 127 & 185 & 169 \\
\hline $\begin{array}{l}\text { Bennachie (whole } \\
\text { borehole) }\end{array}$ & 8.2 & 3.5 & 145 & 135 & 200 & 180 \\
\hline $\begin{array}{l}\text { Bennachie (top } \\
\text { borehole) }\end{array}$ & 8.2 & 3.5 & 127 & 119 & 173 & 158 \\
\hline $\begin{array}{l}\text { Mean (excluding } \\
\text { Bennachie } \\
\text { whole borehole) }\end{array}$ & & & 129 & 121 & 176 & 161 \\
\hline
\end{tabular}

